NEGATIVE CAPABILITY AND THE CAPACITY TO THINK IN THE PRESENT MOMENT: Some implications for leadership practice

\author{
Dr. Peter Simpson \\ Dr. Robert French \\ Peter.Simpson@uwe.ac.uk \\ Robert.French@uwe.ac.uk \\ Bristol Business School \\ University of the West of England \\ Coldharbour Lane \\ Bristol \\ BS16 1QY \\ Telephone $44(0) 1173283468$
}

Peter Simpson has published on strategic and cultural leadership and the place of faith and "not knowing" in leadership and management practice. Recent consultancy and research contracts have involved working with middle and senior management teams on change initiatives and processes of learning in the face of uncertainty.

Robert French has a particular interest in issues of teaching and learning, in leadership, in the experience of role in organisations, and in the application of psychoanalysis in group and organisational contexts. He has written widely in these areas and recently edited the papers of David Armstrong (Organization in the Mind, Karnac, 2005), and has co-edited Rethinking Management Education (Sage, 1996, with Chris Grey) and Group Relations, Management, and Organization (Oxford University Press, 1999, with Russ Vince).

Published as:

Simpson, P. \& French, R. (2006) "Negative Capability and the Capacity to Think in the Present Moment" Leadership, 2(2): 245-255. 


\title{
NEGATIVE CAPABILITY AND THE CAPACITY TO THINK IN THE PRESENT MOMENT: Some implications for leadership practice
}

\begin{abstract}
Two themes that are prevalent in the literature on leadership practice are planning for the future and learning from the past. Here we raise the question of whether attention needs to be given to a third that is not well represented in the literature: the leader's capacity to think in the present. We suggest that such thinking requires the capacity to see what is actually going on, in contrast with what was planned for, expected or intended - even when what is actually going on is uncertain or even unknown. In keeping with the theme of this special issue we demonstrate that attending to the present moment is a refrain both ancient and modern, to be found in eastern and western religion and philosophy whilst having a direct impact on practical modern disciplines, such as psychoanalysis. For example, Wilfred Bion's writings on psychoanalytic theory explore the nature of the mental and emotional capacities demanded by this focus on the present moment and its relationship to the development of thought. Using an idea employed by Bion in this context, we suggest that an important dimension of leadership practice is negative capability, which comprises patience and the ability to tolerate frustration and anxiety. This capability can help the leader to retain the capacity to think in the present moment, even in the face of uncertainty. In this context, important dimensions of leadership practice include the ability to embody key thoughts on behalf of an organization and the capacity to contain the impact of the new thinking that can arise in the present moment.
\end{abstract}

Keywords: change management; emotion; leadership; negative capability; psychoanalytic theory; uncertainty

\section{Introduction}

The present moment can be more unsettling than we normally acknowledge because in the pressure of the moment 'what we know' may not be available to us. What we thought we knew, or did indeed know once, can disappear in action, when we are 'under fire', to use Wilfred Bion's metaphor. We can literally be in a position where we do not know what is actually going on, even if we know what we intended or what we think is occurring.

In this article we pose a question: might leaders be more effective if they acknowledge, and work with the possibility that these - admittedly extreme statements really are true? In other words, does acknowledging the possibility that they do not know enable leaders to remain open to the dynamics of the present moment? The implication for practice, if true, is that interventions in relation to a task may be informed more by the sense-making and the knowledge that arise out of interaction rather than on the basis of preconception and pre-planning (for a classic discussion of this notion, see Weick 1993).

This suggests the need to develop ways to work as much with our ignorance as with our knowing, and to let go of the sense - sometimes the illusion - that we do 
know what we are doing. The difficult tension in this stance is that we all, and leaders more than most, experience pressure to be seen to know - perhaps so that we do not make complete fools of ourselves in front of clients, staff or colleagues.

We do not intend to give the impression that we underestimate the need for leaders to know. Indeed, it is likely that many problems in organizations and in society more widely are exacerbated by 'turning a blind eye' to what is known (Steiner, 1985). However, the current focus on information and on knowledge generation and transfer has led to a situation where ignorance has a tendency to be understood as a state to be done away with as quickly as possible, rather than as a permanent and unavoidable systemic reality to be worked with and potentially to be learned from.

In this article we are raising the possibility that working effectively in the present moment may require us to acknowledge our experience of not knowing, of ignorance, in the present moment. In particular, we consider some implications of this possibility for organizational leaders. In doing so, we draw upon aspects of psychoanalytic theory in which we have found these ideas explicitly addressed. We focus on the work of Wilfred Bion and especially on those aspects of his writings that give explicit attention to the role of negative capability (Simpson, French and Harvey, 2002) and to the importance of the capacity to think in the present moment. In this context we consider a model of leadership that includes:

- the capacity to be available for thoughts that are present in the emotional matrix of organizational experience

- the ability to find thoughts that are available but as yet do not have a thinker

- a preparedness to leave space for a new ideas to be discovered by actively eschewing what appears to be known, desired or remembered

- cultivating the practices of listening, waiting and passivity in contrast to directing and doing

- engaging in developmental processes that enhance the capacity to be present in the leadership role

Before discussing these characteristics of leading in the present moment, we introduce this refrain in its historical context.

\section{The Refrain - from Buddha to Bion, Aurelius to Zen}

The Buddha issued a stirring and unambiguous call to us to live our lives in the present moment: "Do not dwell in the past, do not dream of the future, concentrate the mind on the present moment." It is a refrain that echoes not only across the centuries, but also across cultures, traditions and 'literatures'.

The whole focus of Zen training, for instance, whether in meditation or in calligraphy is on seeking enlightenment, 'an experience of completeness - at each moment' (Tanahashi, 1994: ix; italics added). However, this challenging refrain is equally present in Western thought - in philosophy:

Time is an unwholesome physician, for it deceives the patient daily with the expectations of the future, and before expelling the old pains, it adds new ones to the old and accumulates daily so many evils that through the 
fallacious hope of life it leads to death. We must live today: he who lives tomorrow never lives. (Ficino in Kristeller, 1943: 295)

The present is all we have to live in. Or to lose. (Marcus Aurelius in Hayes, 2003: 167)

in poetry, as in Longfellow's A Psalm of Life:

Trust no Future, howe'er pleasant!

Let the dead Past bury its dead!

Act, - act in the living present!

or in Goethe's Faust II:

Nun schaut der Geist nicht vorwärts, nicht zurück,

Die Gegenwart allein ist unser Glück.

[And so the spirit looks neither ahead nor behind.

The present alone is our joy.] (Act 3, lines 9381-2.)

and even in homespun, 'self-help' sayings:

The past is history; the future's a mystery; the present is a gift (that's why it's called 'the present').

Hadot has pointed out that among the often opposed approaches to philosophy in Ancient Greece this theme - the value of the present moment - 'plays a fundamental role in all the philosophical schools' (Hadot, 1995: 69). In his essay, 'Only in the present is our happiness', he describes ancient philosophy particularly Epicureanism and Stoicism - as 'therapies' that were designed to address the 'human anguish' caused by 'the burden of the past, the uncertainty of the future, and the fear of death'. The goal of these 'therapies' was 'to allow people to free themselves from the past and the future, so that they could live within the present.' (1995: 221-2.)

However, in picking up this richly layered refrain here, our starting point is not the wisdom tradition, but rather the work of the English psychoanalyst Wilfred Bion. Whilst the undertones of the wisdom literature are present in his writings, his - and our - concern is with the immediate demands of professional practice, rather than with philosophical understanding per se. Hence our choice of a theoretician for whom the practice of psychotherapy, in the moment-by-moment interactions of analyst and patient, was of paramount importance.

In focussing on the capacity to think in the present moment, we do not intend to suggest that it is necessary for leaders to ignore or cut themselves off from past and future. Indeed, it might readily be argued that many organizations - and society more widely - would do well both to keep their origins in mind and to be more sensitive to the impact of present actions on future states. However, we ask this question about the leader's capacity to think in the present moment because this refrain - from Buddha to Bion - offers a perspective that is not well represented in the leadership literature. 


\section{Bion and the refrain - leadership through the lens of psychoanalysis}

Bion's work makes a particular contribution to understanding leadership experience in the present moment. His interest in the theme emerged from his broad exploration of the practice of psychoanalysis and the role of the analyst. It was fuelled by his preoccupation with the place and development of thought in human development and hence in psychoanalytic practice.

Bion believed that the 'mechanism' for thinking developed in infants to cope with a 'thought' that was already present in the emotional matrix of their experience in their discomfort, for example, physical or emotional. In a sense, the mother first thinks the thought - 'hunger', for instance - for her baby, but gradually the baby must develop the capacity to think such thoughts for him- or herself. This is a fundamental pattern of human interaction and development that can be repeated later in the experience of analysis: a patient comes into analysis precisely because of 'thoughts' which they may have been encountering in the form of symptoms, emotional states or habits, but cannot access as thoughts (Bollas, 1987). The 'mechanism for thinking' in this case emerges in, or out of, the relationship and relatedness of patient and analyst.

The analogy to leadership is a powerful one. A key dimension of leadership is just this capacity to be available for thought on behalf of a group or organization; that is, to formulate 'thoughts' that are present in the emotional matrix of organizational experience. From this perspective, the leader must endeavour to understand what the system - group, team or organization - requires, in rather the same way that a mother 'knows' what her baby needs. And just as a baby can have other carers, who are able to 'think' for them in this way, so too it may not only be the designated leader who is able to think new thoughts on behalf of an organization. Any organizational role can have a leadership dimension, which is mobilised to the extent that the role-holder demonstrates this capacity to be available for thoughts that are 'around' in the system, whether as ideas or as behaviours, emotional states or other 'symptoms'.

What we actually see of leadership, however - from 'outside', as it were - tends to be action not thought: we expect (and tend to analyse) 'decisive action', not 'reflective inaction' (Simpson, French and Harvey, 2002). Perhaps because 'to lead' has always implied the ability 'to cause others to go with one' (Chambers Dictionary of Etymology), and also as a result of the central stories and myths on which Western society draws, the focus of attention has tended to be on leadership-in-action. We tell stories about leaders and analyse or measure leadership in terms of events and outcomes, not thought. Thus, our tendency is to focus on the fate of a thought once it has emerged. At that point, the leader's ability to transform thought into action becomes central, and it seems selfevident that the role, character and behaviours of leaders relate to their ability to embody or 'champion' the thought, in order to mobilise the energies and resources available to the organization.

Bion's contribution, by contrast, allows us to maintain our focus on the place and importance of thinking. Central to his work, whether as practitioner or teacher, is the attention he gave to the prior stage: to the potentially creative relationship 
between known and unknown, between certainty and ignorance. He was also aware of the opposite of this relationship, that is, of our tendency to avoid or to resist thinking. He constantly reminded his colleagues of the 'curious business' by which we 'closure off what [we] don't want to see or hear' (Bion, 1978: 9), giving in instead to the temptation 'always to engage upon something familiar' (Bion, 1990: 5).

Leadership does, of course, take many forms. At the more transactional end of the scale, it can be thought of as closely related to management: giving a lead is an important function even under conditions of relative certainty. At the other end of the scale, however, leadership is evoked precisely in moments or situations where we do not know - either what we are doing, or where we are going, or how to get to where we want to be - and yet we still have to be able to 'cause others to go with us'. In line with the our discussion here, Peter Reason (1994) suggests that transformational leadership 'is based on an effort to be aware of the present moment in all its fullness, recognizing that such effort can never be completely successful. Transforming power is not just open to feedback, but is actively vulnerable in seeking challenge and contradiction, seeking out ways in which its exercise is blind and unaware.' (Reason, 1994: 331-2)

So the Buddha's refrain finds a very clear echo in Bion's work. It is most explicitly expressed in his exhortation to his psychoanalytic colleagues not to be distracted by past or future - neither by their memory of how the patient was (in the last session, week or month), nor by their hopes for the patient's future, for a 'cure'. The idea is captured in his repeated, mantra-like statements about memory and desire: 'Do not remember past sessions. The greater the impulse to "remember" what has been said and done, the more need to resist it. ... Desires for results, "cure" or even understanding must not be allowed to proliferate.' (Bion, 1967a: 272-3.)

\section{Negative capability and the capacity to think in the present moment}

Bion may be best known for this advice to the analyst 'to impose on himself a positive discipline of eschewing memory and desire' (Bion, 1970: 31). The task for the analyst in each new session is to tune in to whatever 'thought' the patient hopes to communicate that day, whether in a story or a silence, a dream or a particular emotional tone. In Bion's view, therefore, the freight of a psychoanalytic training did not lie in the acquisition of theoretical knowledge per se, however important that might be, but in the far more difficult acquisition of a capacity to work in the present moment 'without memory, desire, understanding' (Bion, 1970: 43). Indeed, he was keenly aware of the potential for theory to be used defensively: 'We learn these theories - Freud's, Jung's, Klein's - and try to get them absolutely rigid so as to avoid having to do any more thinking.' (Bion, 1978: 6)

One of Bion's most graphic expressions of this need to stay thinking in the present comes in a talk he gave in New York towards the end of his life: 'Discard your memory; discard the future tense of your desire; forget them both, both 
what you knew and what you want' - and the reason, he suggests, is 'to leave space for a new idea.' (Bion, 1980: 11) It is as though there are 'thoughts' circulating in the system - in the case of psychoanalysis, this means in the evolving relationship between patient and analyst - 'thoughts' which are, as he put it earlier, 'in search of a thinker' (1967b: 166). Such 'thoughts' can only find expression in a space that has been cleared of the clutter of memory and desire, even the desire for understanding: 'A thought, an idea unclaimed, may be floating around the room searching for a home. Amongst these may be one of your own which seems to turn up from your insides, or one from outside yourself, namely, from the patient.' (1980: 11.)

Hence his injunction to the analyst to cultivate a state of mind which enables him or her to let go of the security of the known, in order to engage with the truth of each encounter with their patient in the moment. Bion used the simple word 'patience' to capture the essence of this capacity. However, this state of mind - for which he also borrowed from the poet John Keats the term 'negative capability' (Keats, 1970: 43; Bion, 1970: 125) - is not a fashionable one in organizational contexts today (though not entirely absent; see Bennis, 1998: 148; Handy, 1989). This 'patience' demands passivity - a word that has overtones of suffering as well as of inaction and receptivity (Vanstone, 1992) - and is based on listening and on waiting, rather than on the more obvious leadership modes of activity and telling.

Bion did not advocate patience for its own sake, however. For him, as for Keats, the intended outcome of negative capability was 'achievement'. Not knowing tends to stimulate high levels of uncertainty and anxiety and is a threat to fresh thinking, whether in the analytic pair or in an organizational context. As a result, there is often pressure to invoke prior knowledge - that may no longer apply - or to adopt a new certainty too quickly, before a new pattern has had the chance to evolve (Bion, 1970: 124). Hence Eisold's definition of negative capability as 'precisely the ability to tolerate anxiety and fear, to stay in the place of uncertainty in order to allow for the emergence of new thoughts or perceptions' (Eisold, 2000: 65).

Thus, the 'negative' of negative capability also implies a 'positive'. Just as it is impossible to split apart the positive and negative poles of a magnet, so too it may be misleading to try to separate the 'positive' pole of leadership, which we called above 'decisive action', from the patient and reflective pole, represented by the term negative capability. The more turbulent and uncertain the environment, the more the ability to produce results may depend precisely on a negative capability that allows us to tolerate ambiguity and to remain 'content with half knowledge' (Ward, 1963: 161).

Underpinning Bion's theory and informing his practice - indeed, the whole basis of the call to 'concentrate the mind on the present' - is his experience of the transformative power of 'truth-in-the-moment'. As Bion himself put it, 'healthy mental growth seems to depend on truth as the living organism depends on food' (1965: 38). Bion designated this 'truth' as ' $O$ ', signifying the imminent reality of anything whatever in context (Bion, 1965: 147), thereby locating this reality very clearly in the experience of the present moment. He insisted too that whilst the pursuit of such truth is essential, truth itself is also radically out of reach: not only unknown but, ultimately, unknowable. Hence his choice to represent this 'truth' 
with the enigmatic symbol ' $O$ ' - itself an ancient refrain of great symbolic or iconic significance (French and Simpson, 2001: 56-7).

In dwelling on Bion's ideas, however, we do not intend to propose the role of psychoanalyst as a model for organizational leaders - whether in relation to traits, styles or behaviours. Rather, our interest is in a refrain which, rather like the chorus of a traditional ballad, can create a pause in the narrative, reminding us of themes that might otherwise be forgotten or submerged in the action.

\section{An application to leadership: the containment of emotion}

As we have suggested, the underlying thrust of Bion's own refrains runs counter to current organizational thinking - slow down, listen, wait, and refrain from intervening; eschew memory and desire; see truth as the stimulus for learning and mental growth. The pursuit of truth has been replaced by the pursuit of targets. The principle of performativity, which pervades our culture at every level, puts pressure on organizational members - and their leaders above all 'to subordinate knowledge and truth to the production of efficiency' (Fournier and Grey, 2000: 17). We would suggest that the dominant image and language of leadership focuses on this 'production of efficiency', on decisive action in the pursuit of future outcomes and goals. It is a focus that may leave too little space for the reflection which is sometimes necessary for a new thought to emerge or be found in the present moment. Those who do take 'time out' from work, to attend a course or an 'away day', for example, frequently observe that the most beneficial aspect of the experience is having the time and space to do some thinking.

The creative potential of reflective inaction in leadership practice, and of focussing on the present moment, is well illustrated in a paper on leadership in the prison service (Abbott, 2000). In this paper, Abbott emphasises the benefits to be gained from the Prison Governor 'walking the landings' of the prison and meeting people 'where they actually work'. In effect, he outlines the potential for creating a space where 'old thoughts' can become 'new thoughts' through the mobilisation of patience or negative capability.

The overwhelming sense in his description of this activity is of passivity and receptivity and their transformative potential, and this sense is reflected in the verbs he uses. He talks, for example, of 'the opportunity to be seen', 'the opportunity to listen', and 'the opportunity to observe'. Most explicitly, he writes: 'Above all else it [walking the landings] provides the opportunity to feel the institution and having felt it to work with and on the feeling. The task is to absorb the emotion and thus allow people to take up their role free of negative emotion, which detracts from their performance. Often just being there will remove the emotion. Often just listening to the anger will move it.' (Abbott, 2000: 4; all italics added.)

It is important to note that Abbott does not deny the wider range of leadership or management skills and capacities that his job demands. Nor does he advocate inaction for its own sake. He clearly used his negative capability for a creative 
purpose in relation to the task. Thus, he also employs active verbs; for example: walking the landings offers him the opportunity 'to do casual management casework', and 'feeling the institution' makes it possible 'to work with and on the feeling'. Above all, however, he is pointing to a dimension of 'thinking in the present moment', which seems close to Bion's sense of finding a thought which is there, 'a thought in search of a thinker'. By meeting people 'where they actually work' and making himself available as a container for their concerns, Abbott allowed his staff 'to take up their role free of negative emotion, which detracts from their performance.' Reflective inaction on the part of the prison governor enabled a greater capacity for effective action on the part of his staff. One might say that his own negative capability in his leadership role seems to have acted as a form of negative capability for the wider system.

Abbott's description indicates that the value and outcomes of exercising leadership in this way - that is, from paying close attention to and containing emotions in the organization - may be measurable in terms of practical actions. There may indeed be immediate work to be done and important information to be gained that will translate into new strategies or practices. However, this is not the whole story. It also suggests that 'just being there' and 'just listening' - in other words, 'just' offering containment - may be enough to make a difference. This is a much broader view of the importance of working with emotion than that generally portrayed, for example, in the literature on 'emotional intelligence' in relation to leadership. Such literature tends to take a more cognitive-behavioural stance and to talk in terms of the 'repair' of negative emotions and of 'using' emotions 'in functional ways' (George, 2000: 1036; italics added; see also Armstrong, 2005: 90-110).

\section{Learning to think and lead in the present moment}

Bion frequently used a quotation from Maurice Blanchot: 'La réponse est le malheur de la question' - 'the answer is the misfortune or disease of curiosity - it kills it' (Bion, 1978: 21-2). In doing so, he was pointing to the tendency which he called 'filling the empty space' - filling it, that is, with answers or with knowing (Bion, 1991: 578). In his view, it is in the 'empty space' of the present moment that a new thought may arise or be discovered.

The anxiety that tends to drive us all towards a desire for certainty - the need to have an answer at least, if not the answer - is likely to be particularly strong for those in leadership roles. Externally imposed changes are one thing, but anyone who initiates change also inevitably stimulates uncertainty. For example, a leader who wishes to encourage others to take their own authority to lead may refuse always to 'lead from the front' (French, Simpson and Harvey, 2003). The result can be that team or organizational members experience and communicate, in subtle and not so subtle ways, their hatred of 'no answer' - in this case, what they experience as, and take to be, 'no leader[-ship]'. The leader must be able to cope with their reactions, if he or she is to avoid being pulled back into patterns of dependency that may, in the long term, be as disabling as they are comforting. Anyone who takes up a role that demands giving a lead, whether as teacher, trainer, consultant, manager, or leader, will be familiar with this dynamic. Faced by 'no answer', staff, colleagues, students, or clients can 
exert enormous pressure for someone else to find and supply a solution, rather than moving into the awkward ('empty') space where they have to think for themselves.

As one leader put it to us, when describing the impact of a major change process in her organization, a College of Further Education, 'the behaviour of the organization became extremely strange'. Attacks came not only from staff who held entrenched positions, but also from outside, in the press, for example, where accusations of serious personal and professional misconduct were made. As a result,

There was also - what was scary - the need for me to go into myself, and actually challenge my own integrity. And I know l've worked with people hubristic leadership - where they think they are right. And how the hell do they know? And so all that notion about: is this attack warranted? Am I really off my head trying to do what it is we are doing here?

The capacity to remain without a solid sense of knowing - avoiding what she called 'hubristic leadership' that insists on being right - needs to be learned and sustained just as much as other, more outcome focussed leadership capacities, skills and competences. Individual and group psychotherapy, for instance, can help individuals to understand their own habitual patterns of thinking and acting. A similar developmental outcome can be achieved through experiential learning approaches such as group relations training conferences or organizational role analysis (Gould, Stapley and Stein, 2004; Miller, 1990; Reed, 1976). The Buddha's refrain and its echoes in other traditions also point to often quite practical and down-to-earth exercises designed to develop the capacity to think in the present (Hadot, 1995; Sorabji, 2000).

This particular leader was explicitly aware of working at this task of selfawareness and self-development. For instance, she consciously took 'time out' for herself - to see friends, to read or to go to the cinema. She would visit art galleries, where she would take up a particular frame of mind: instead of seeking out specific pictures, she would, as it were, allow them to seek her out. She did this by suspending her critical faculties as she walked the gallery, until a picture captured her attention. She would then spend time with that one picture. Her assumption was that it had caught her attention because in some way it reflected something of her present work situation or resonated with her current emotional relationship to work and to colleagues. She had discovered that by using the picture as a kind of echo chamber for her experience as a leader, something could be learned from the experience of just staying with the image and allowing it to have an affect on her. Similarly, she had set up with friends a regular meeting where they would share their dreams - not using the dream material to shed light on the psychological state of the individual dreamer, but rather approaching the dreams as social artefacts that could give another level of insight into unconscious dimensions of their experience (see Lawrence, 2005). In this way, she would work simultaneously on known and unknown, conscious and unconscious, rather as Abbott described 'feeling the institution' and then working on and with the feeling. Finally, she also used the professional support available from organizational role analysis (Armstrong, 2005). 
While work of this kind might be conceptualised simply as an exercise in self development, this was not the aim for this leader. Instead, by working on herself in this way, she was better able to monitor her experience in the leader role and, as a result, to use that experience to understand the state of the organization more widely. In the terms of this article, she was deliberately attempting to develop her ability to 'be present' in her role. It is a thought and a practice that return us to the philosophical tradition with which we started. This tradition recognised the 'indissoluble link between the delimitation of the self and the delimitation of the present moment': 'It is only when I am active, either within myself or upon the outside world, that I am truly myself and at liberty; and it is only in the present moment that I can be active.' (Hadot, 1998: 119)

\section{Concluding thoughts}

In the current organizational context of radical uncertainty, the ability to lead demands precisely the capacity to tolerate ambiguity, uncertainty and complexity in the present moment. When the pressure is on, however, to meet targets based exclusively on the measurement of outputs, the 'default' position tends to be control. In conditions such as these it seems inevitable that this 'negative' capacity will tend to be ignored or to pass unnoticed, and will atrophy by being excluded from dominant organizational discourses. In such an environment, how is one to attribute value to behaviours that have only low status in the discourse of organizations, such as waiting, patience, passivity, observing, imagination, detachment, disinterest, trust, and humility?

More work is needed to explore and to describe in detail what enables leaders to go on thinking in the present moment, despite the complexity of the conflicting and ambiguous demands and projections they experience in role. The sea of information threatens to engulf rather than to support. At the macro and micro levels, we must ask whether we might be well advised to focus more of our time and energy not on producing more of the same solutions, based on knowledge and control, but rather on leading by concentrating our minds on the present moment, as the place where new knowledge may emerge. 


\section{References}

Abbott, W.A. Prison management. (2000) Paper given in the Tavistock Clinic Series, 'Programme of Dialogues: Worlds of Leadership 2000', 6 July.

Armstrong, D. (2005) Organization in the Mind: Psychoanalysis, Group Relations, and Organizational Consultancy. Occasional Papers 1989-2003. London: Karnac Books.

Bennis, W. (1998) On Becoming a Leader. London: Arrow. (1 $1^{\text {st }}$ publ. 1989).

Bion, W.R. (1965) Transformations. London: William Heineman Medical Books. [Reprinted London: Karnac Books, 1984.]

Bion, W.R. (1967a) 'Notes on memory and desire'. Psychoanalytic Forum, 2: 271-280.

Bion, W.R. (1967b) Second Thoughts. London: William Heineman Medical Books. [Reprinted London: Karnac Books, 1984.]

Bion, W.R. (1970) Attention and Interpretation. A Scientific Approach to Insight in Psycho-Analysis and Groups. London: Tavistock. [Reprinted London: Karnac Books, 1984.]

Bion, W.R. (1978) Four Discussions with W.R. Bion. Strath Tay, Perthshire: Clunie Press.

Bion, W.R. (1980) Bion in New York and São Paulo. Strath Tay, Perthshire: Clunie Press.

Bion, W.R. (1990) Brazilian Lectures: 1973 São Paulo; 1974 Rio de Janeiro/ São Paulo. London: Karnac Books.

Bion, W.R. (1991) A Memoir of the Future. London: Karnac Books.

Bollas, C. (1987) The Shadow of the Object: Psychoanalysis of the Unthought Known. London: Free Association Books.

Dawkins, R. (1989) The Selfish Gene. Oxford: Oxford University Press.

Eisold, K. (2000) The rediscovery of the unknown: an inquiry into psychoanalytic praxis. Contemporary Psychoanalysis, 36(1), 57-75.

Fournier, V. and Grey, C. (2000) At the critical moment: Conditions and prospects for critical management studies. Human Relations, 53(1), 7-32.

French, R. and Simpson, P. (2001) Learning at the edges between knowing and not-knowing: 'Translating' Bion. Organisational and Social Dynamics, 1(1), 54-77. 
French, R., Simpson, P. and Harvey, C. (2003) A hidden side of leadership: Researching the 'language of unsaying'. Second Annual International Conference on Leadership Research, Lancaster University, December.

George, J.M. (2000) Emotions and leadership: The role of emotional intelligence. Human Relations, 53(8), 1027-55.

Gould, L.J., Stapley, L.F. and Stein, M. (eds) (2004) Experiential Learning in Organizations: Applications of the Tavistock Group Relations Approach. London: Karnac Books.

Hadot, P. (1995) Philosophy as a Way of Life. Ed. with an Intro. A.I. Davidson. Oxford: Blackwell.

Hadot, P. (1998) The Inner Citadel: The Meditations of Marcus Aurelius. Tr. M. Chase. Cambridge, Mass.: Harvard University Press.

Handy, C. (1989) The Age of Unreason. London: Business Books Ltd.

Hayes, G. (tr.) (2003) Marcus Aurelius 'Meditations': A new translation. London: Weidenfeld and Nicolson

Keats, J. (1970) The Letters of John Keats: A selection. ed. Gittings, R., Oxford: Oxford University Press.

Kristeller, P.O. (1943) The Philosophy of Marsilio Ficino, tr. V. Conant. New York: Columbia University Press.

Lawrence, W.G. (2005) Introduction to Social Dreaming: Transforming Thinking. London: Karnac Books.

Miller, E. (1990) Experiential learning in groups I: The development of the 'Leicester Model'. In E.L. Trist \& H. Murray (eds), The Social Engagement of Social Science: A Tavistock Anthology, Vol. I, The Socio-Psychological Perspective. London: Free Association Books: 165-85.

Reason, P. (1994) 'Three approaches to participative inquiry', in N.K. Denzin and Y.S. Lincoln, Handbook of Qualitative Research. Thousand Oaks, Calif.: Sage.

Reed, B.D. (1976) 'Organisational role analysis', in C.L. Cooper (ed.), Developing Social Skills in Managers, London: Macmillan, 89-102.

Simpson, P., French, R. and Harvey, C.E. (2002) Leadership and negative capability. Human Relations, 55(10), 1209-26.

Sorabji, R. (2000) Emotion and Peace of Mind. From Stoic Agitation to Christian Temptation. Oxford: Oxford University Press.

Steiner, J. (1985) Turning a blind eye: The cover-up for Oedipus. International Review of Psycho-Analysis, 63: 241-51. 
Tanahashi, K. (1994) 'Preface: On positive emptiness', in K. Tanahashi and

Tensho D. Schneider (eds), Essential Zen, San Francisco: HarperCollins, viii-x.

Vanstone, W.H. (1982) The Stature of Waiting. London: Darton, Longman and Todd.

Ward, A. (1963) John Keats: The Making of a Poet. London: Secker and Warburg.

Weick, K.E. (1993) The Collapse of Sensemaking in Organizations: The Mann Gulch Disaster. Administrative Science Quarterly, 38: 628-652 